Research, part of a Special Feature on Exploring Opportunities for Advancing Collaborative Adaptive Management (CAM): Integrating Experience and Practice

\title{
Navigating a Murky Adaptive Comanagement Governance Network: Agua Fria Watershed, Arizona, USA
}

\author{
Cameron Childs $^{1}$, Abigail M. York ${ }^{2}$, Dave White ${ }^{3}$, Michael L. Schoon ${ }^{4}$ and Gitanjali S. Bodner ${ }^{5}$
}

\begin{abstract}
Adaptive comanagement endeavors to increase knowledge and responsiveness in the face of uncertainty and complexity. However, when collaboration between agency and nonagency stakeholders is mandated, rigid institutions may hinder participation and ecological outcomes. In this case study we analyzed qualitative data to understand how participants perceive strengths and challenges within an emerging adaptive comanagement in the Agua Fria Watershed in Arizona, USA that utilizes insight and personnel from a long-enduring comanagement project, Las Cienegas. Our work demonstrates that general lessons and approaches from one project may be transferable, but particular institutions, management structures, or projects must be place-specific. As public agencies establish and expand governance networks throughout the western United States, our case study has shed light on how to maintain a shared vision and momentum within an inherently murky and shared decision-making environment.
\end{abstract}

Key Words: adaptive comanagement; Agua Fria watershed, Arizona; governance network; qualitative research

\section{INTRODUCTION}

Adaptive comanagement approaches address complex socialecological problems that cross social, environmental, and political boundaries through learning-by-doing and broad stakeholder participation. This approach, when executed effectively, enhances resource management in the face of uncertainty and complexity (Ruitenbeek and Cartier 2001, Gunderson and Holling 2002, Armitage et al. 2009, Stockholm Resilience Centre 2012). When collaboration between agency and nonagency stakeholders is mandated, however, rigid institutions may hinder participation and ecological outcomes (Dietz et al. 2003, Lubell 2004, Ostrom 2005). Social variables such as development of shared motivations, trust, and interpersonal empathy, are known to enhance adaptive comanagement in well-established arrangements (Wondolleck and Yaffee 2000, Ansell and Gash 2007, Armitage et al. 2009, Plummer 2009). But which factors affect adaptive comanagement within a governance network initiated in part through top-down government decision making? Our study empirically contributes to the adaptive comanagement literature by having investigated which variables enhance or erode social relationships within a governance network.

The Agua Fria Watershed in Arizona, USA is "one of the most complicated, challenging, natural, and human landscapes you can imagine, and right next door to Phoenix," said Secretary Bruce Babbitt (Allen 2002). Three government agencies and twenty-three nongovernment stakeholders are developing a coordinated resource management plan for two grazing allotments covering 26,325 ha comprised mainly of semidesert grassland with some interior woody species and riparian areas home to diverse wildlife (Stone 2007). A coordinated resource management plan is created through the U.S. Department of Agriculture's Natural Resource Conservation Service and is specifically intended to coordinate the management actions when a landowner is grazing on public lands. Increasingly, coordinated resource management plans are used to coordinate multi-agency resource management activities (FernándezGiménez et al. 2004), such as, in our case, those of the Natural Resource Conservation Service, U.S. Department of Agriculture Forest Service, and the U.S. Department of the Interior Bureau of Land Management. In Agua Fria, special attention by the coordinated resource management plan is placed on restoring habitat for pronghorn antelope, native fishes, and grassland birds. The cultural resources are especially significant because the area is home to Perry Mesa, a largely intact prehistoric landscape (Kruse 2007). Hunters, campers, and other recreation visitors use the allotments, though the area has not been developed for recreational use.

This adaptive comanagement was in part a top-down effort by the Bureau of Land Management test out whether the process and approach are scalable across the region. Using results from semistructured interviews, we addressed: (1) What social variables influence emerging institutions in the earliest phase of adaptive comanagement? (2) What actions can be taken to enhance or erode social relationships within a governance network? Interviewees were selected using a maximum variation sampling strategy that included agency representatives, financially vested organizations, advocates and stakeholders who attended meetings, and organizations identified as important but who opted not to participate in the

\footnotetext{
${ }^{1}$ School of Sustainability, Arizona State University, ${ }^{2}$ School of Human Evolution and Social Change, Center for the Study of Institutional Diversity, Arizona State University, ${ }^{3}$ School of Community Resources and Development, Decision Center for a Desert City, Arizona State University, ${ }^{4}$ School of Sustainability, Center for the Study of Institutional Diversity, Arizona State University, ${ }^{5}$ The Nature Conservancy, Tucson, Arizona
} 
process. Data were reduced and analyzed using qualitative coding techniques that allowed for inductive themes to emerge naturally from the stakeholders' statements.

Within somewhat murky decision-making environments, adaptive comanagement must build trust and commitment. In this case, effective facilitation with a team seasoned by experience with the 25-year-old Las Cienegas Project managed interpersonal relationships conflicts, and built trust and commitment through facilitation processes. But structural adjustments are needed if the governance network at Agua Fria is to stand up to the test of time. Our case study has contributed to a growing adaptive comanagement literature that is providing an empirical assessment of whether and how lessons from long-enduring adaptive comanagement projects may effectively cross pollinate nascent projects or may be scalable to other public and private lands within or outside the USA.

\section{EXTANT LITERATURE}

Humans struggle to manage complex social-ecological systems wrought with uncertainty and change (Gunderson and Holling 2002). Collaborative adaptive governance allows us to manage our environment in the face of uncertainty, complexity, and rapid change through incorporation of scientific information and local ecological knowledge (Folke et al. 2011, Stockholm Resilience Centre 2012). These approaches stand in stark contrast to the top-down systems developed over the last century by centrally controlled government agencies (Dietz et al. 2003), which inhibit inclusive participation (Holling 1978, Walters 1997, Colding et al. 2003, Dietz et al. 2003, Armitage 2005).

In the last 25 years, emerging governance tactics have incorporated systems thinking and broad participation (Pahlwostl et al. 2007, Plummer and Armitage 2007) and have been most effective when mobilized around a shared goal or challenge (Wondolleck and Yaffee 2000). Recently, government entities wanting to emulate these past successes have encouraged, and even mandated, collaboration at the highest levels (Kagan 1999, Lubell 2004); in mandated cases, shared goals may not exist (Wondolleck and Yaffee 2000). As government agencies increasingly encourage collaborative institutions, the debate between whether collaboration is a good tool rather than just a good idea becomes even more important (Bardach 1998, Lubell 2004). Though processes for working together may enhance social relationships, effective translation of intention into action is not guaranteed (Kenney 2000, Susskind et al. 2010). Adaptive comanagement governance networks reflect wider trends within public management that focus on shifting or sharing authority, information, and implementation with private actors and civil society (Agarnoff and McGuire 2001, Klijn and Skelcher 2007). Like other governance networks (Stoker 1998), adaptive comanagement pushes beyond the authority of the government and establishes somewhat blurred decisionmaking boundaries.

\section{Adaptive comanagement}

Adaptive comanagement is an adaptive governance strategy that blends adaptive management (Holling 1978) with broad stakeholder engagement to govern natural resources in the face of incomplete information and change (Gunderson and Holling 2002, Armitage et al. 2007). This approach integrates collaboration and learning to expand the breadth of knowledge and boost creative alternatives to institutional structures that contribute to sustainability challenges (Colding et al. 2003, Armitage 2005, Polasky et al. 2011). In adaptive comanagement, learning takes place when strategies are assessed and adjusted based on new evidence (Lee 1999, Armitage et al. 2007, Pahl-wostl et al. 2007, Plummer and Armitage 2007). This allows participants to operate despite uncertainty about future ecological conditions and management resources.

Adaptive comanagement is related to a number of collaborative, place-based, and discourse-based approaches that have been described in the applied natural resource management literature as promising avenues for negotiation, conflict management, building of credibility and trust, and fulfillment of the ideals of representative governance in a democratic society (Conley and Moote 2003). Such collaborative approaches include community-based collaboratives (Moote et al. 2000), partnerships (Wondolleck and Yaffee 2000), community-based conservation (Western et al. 1994), grass-roots ecosystem management (Weber 2000), and community-based environmental protection (Filbin et al. 1997). The proliferation of these strategies in both theory and practice is indicative of the broad shift away from "TechnoReg" (Daniels and Cheng 2004) processes that are dominated by scientific expertise and technical solutions.

Adaptive comanagement research has led to broad syntheses that seek to uncover basic principles of adaptive comanagement (see for example Armitage et al. 2009, Plummer 2009). From this literature, we focused our attention on interpersonal and structural factors to uncover the most important variables that enhance or erode commitment to adaptive comanagement in its earliest stages. Over the last decade many conceptualizations (Pomeroy and Berkes 1997, Plummer and Fitzgibbon 2004, Carlsson and Berkes 2005), syntheses (Armitage et al. 2009, Plummer 2009), and case studies (Uychiaoco et al. 2005, Olsson et al. 2007, Pomeroy 2007) have identified variables that play a role in the process of adaptive comanagement. Armitage (2007) identified conditions reminiscent of Ostrom's design principles (2005) that are necessary but not sufficient for effective adaptive comanagement, such as well-defined resource boundaries, inclusion of affected participants, sharing knowledge, and supportive policy environment. Pomeroy (2007) treats the 
biological, social, economic, and knowledge contexts of the region and network as exogenous influences that participants have little control over. Plummer (2009) built on this work to synthesize a set of endogenous variables, or factors that internal participants can control, from a decade of adaptive management, and collaborative governance case studies. We unpacked what participants identified as strengths and challenges of adaptive comanagement paying particular attention to the scalability of this process and the issues associated with network governance.

\section{STUDY CONTEXT}

In June 2011, two federal agencies-the U.S. Department of the Interior Bureau of Land Management and the U.S. Department of Agriculture Forest Service-Tonto National Forest - and the Arizona Game and Fish Department agreed to develop a coordinated resource management plan, using templates and agreements established by the Natural Resource Conservation Service for use when a conservation plan is created for a grazing operation on public lands (U.S. Department of Agriculture 2007). Rigid regulatory processes, such as the National Environmental Policy Act, are required when an agency makes changes to land that may have environmental impact. Coordinated resource management plan is a complementary process that the landowner may choose to embark upon in order to foster inclusive decision making. This voluntary process was developed in response to increased mandates to include stakeholders in decision making, especially by the Bureau of Land Management. Coordinated resource management plan processes are voluntarily initiated by landowners, i.e., in this case, the Bureau of Land Management, Tonto National Forest, and Arizona Game and Fish Department. At the Agua Fria, the three agencies agreed to comanage two federal grazing allotments connected with 80 deeded ha, the Horseshoe Ranch, which is owned by the Arizona Game and Fish Department. The coordinated resource management plan covers 26,532 ha on the Bureau of Land Management's Horseshoe allotment and the Tonto National Forest's Copper Creek allotment (Fig. 1). The Horseshoe allotment is located within the culturally and ecologically sensitive Agua Fria National Monument.

The three agencies initiated the coordinated resource management plan process for several reasons. For the last 25 years the Bureau of Land Management field staff in Tucson, Arizona has been experimenting with adaptive comanagement on one of its ranching allotments in the Las Cienegas National Conservation Area, through which they built strong stakeholder partnerships that received national attention (Caves et al. 2013). In summer 2011, staff from the Agua Fria National Monument traveled over $322 \mathrm{~km}$ south to visit a Las Cienegas planning meeting and was inspired by Las Cienegas's approach. Concurrently, the Arizona Game and Fish Department purchased the ranch property on the Agua Fria
Fig. 1. Agua Fria Adaptive Co-Management Area, Arizona, USA.

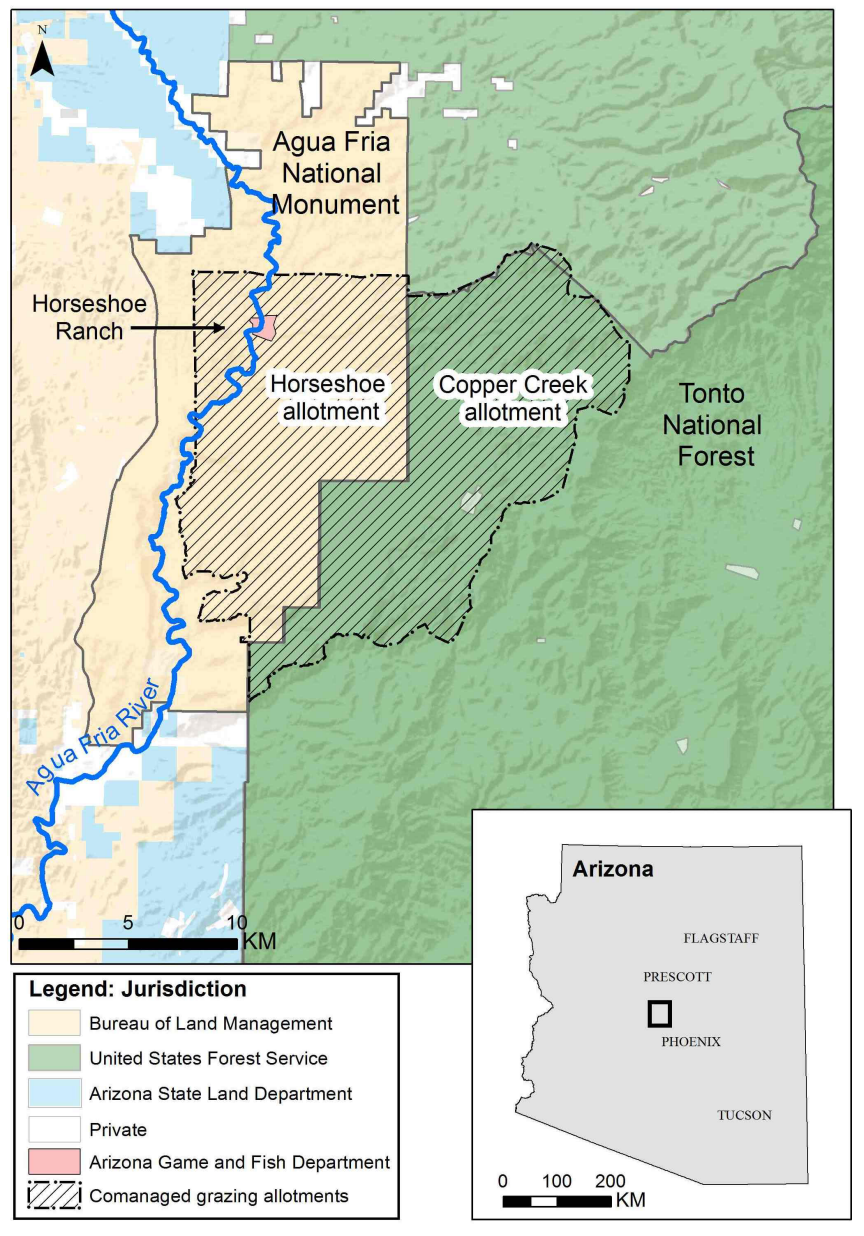

National Monument to be used for wildlife habitat protection and restoration. After this acquisition, the Bureau of Land Management, Tonto National Forest, and Arizona Game and Fish Department began a conversation about comanagement, and signed a memorandum of understanding that kicked-off the adaptive comanagement process. The memorandum outlined broad goals such as wildlife, terrestrial, and riparian conservation and a legal commitment to maintain domestic livestock grazing on the allotments. With financial support from The Nature Conservancy, a nonprofit conservation organization, and the Bureau of Land Management, the Las Cienegas facilitation team was granted an opportunity to pilot their adaptive comanagement process in Agua Fria. To assist with the comanagement process, the convening agencies agreed to work with an experienced facilitator from an environmental consulting firm, with two staff from The Nature Conservancy and the Bureau of Land Management staff serving as experts in adaptive management. 
Table 1. Stakeholder analysis: overview.

\begin{tabular}{|c|c|c|c|}
\hline Type & Resource & Organization & $\begin{array}{c}\text { Interviewees } \\
\text { (no.) }\end{array}$ \\
\hline Academic & Riparian & Arizona State University & 2 \\
\hline Academic & Cultural & Arizona State University Legacies & 1 \\
\hline Advocacy & Landscape & Sierra Club & 1 \\
\hline Advocacy & Landscape & Western watershed & 1 \\
\hline Agency & Recreation & $\begin{array}{l}\text { U.S. Department of Agriculture Forest Service } \\
\text {-Tonto National Forest }\end{array}$ & 4 \\
\hline Agency & Wildlife & Arizona Game and Fish Department & 3 \\
\hline Agency & Landscape & Bureau of Land Management & 2 \\
\hline Agency & Landscape & Natural Resource Conservation Service & 2 \\
\hline Consultant & Landscape & AMEC (environmental consulting) & 1 \\
\hline Facilitator & Landscape & Facilitation Team & 3 \\
\hline NGO & Landscape & Friends of Agua Fria National Monument & 3 \\
\hline NGO & Cultural & Archeology Southwest & 1 \\
\hline NGO & Wildlife & Sonoran Audubon & 1 \\
\hline NGO & Botany/cultural & Desert Botanical Gardens & 1 \\
\hline NGO & Wildlife & Audubon Arizona & 1 \\
\hline NGO & Landscape & Upper Agua Fria Watershed Partnership & 1 \\
\hline NGO & Landscape & Phoenix Zoo & 1 \\
\hline NGO - vested & Wildlife & National Wild Turkey Federation & 1 \\
\hline NGO - vested & Wildlife & Arizona Wildlife Federation & 1 \\
\hline NGO - vested & Wildlife & The Nature Conservancy & 1 \\
\hline Permittee & Grazing & Permittee & 1 \\
\hline Politician & Landscape & Yavapai County Supervisor & 1 \\
\hline
\end{tabular}

\section{ADAPTIVE COMANAGEMENT PROCESS}

Through a series of monthly meetings, the core team established a MOU in August 2011, which formalized comanagement and purposefully blurred decision-making authority (Fig. 1). After five months of agency-driven preparation, the team began to engage nongovernmental stakeholders in November 2011. The convening team identified individuals and groups relevant to the study area based on sector (government, NGO, business, landowner, academic), jurisdiction (local, state, federal, tribal), and resource (riparian, wildlife, grassland, recreation, cultural), and on a smaller set of subcategories such as financially vested, local knowledge, and advocacy. MOU objectives were based on the agencies' existing plans and mandates, but within this space all stakeholders worked together to outline specific goals.

Seventy-five agency and nonagency individuals make-up the planning team, though 20 attend meetings consistently. To manage the large group, a subgroup structure was created, comprised of an interagency coordination group that has shared decision authority and the planning team comprised of all stakeholders including both agency and nonagency participants. The subgroup influences decisions through participatory engagement but it does not have authority.

\section{METHODS}

Using an interpretive research paradigm (Hemingway 1990, Schwandt 1994), we employed a case study design with indepth and detailed exploration of a bounded system incorporating multiple sources of data (Creswell 2009). Interpretive research often utilizes data-collection strategies, such as interviews and participant observations, which facilitate a more contextual and nuanced understanding of perspectives than is possible through survey research.

The data analyzed for this study were generated through a series of semistructured interviews conducted between October 2011 and March 2012. We used a nonprobability, purposive, maximum variation sampling strategy (Miles and Huberman 1994, Patton 1990) to identify individuals representing all organization types and resource priorities that had an interest in the coordinated resource management plan process (Table 1). This process involved deliberately selecting a range of individuals from a heterogeneous population. Maximum variation sampling generates data useful for producing case descriptions that illustrate unique perspectives as well as shared patterns or commonalities across participants. The first round of interviews was with agency representatives and consistent attendees of the meetings. The second round of interviews was with financially vested 
Fig. 2. Timeline, April 2011 to March 2012.

\section{Phases 1 and 2}

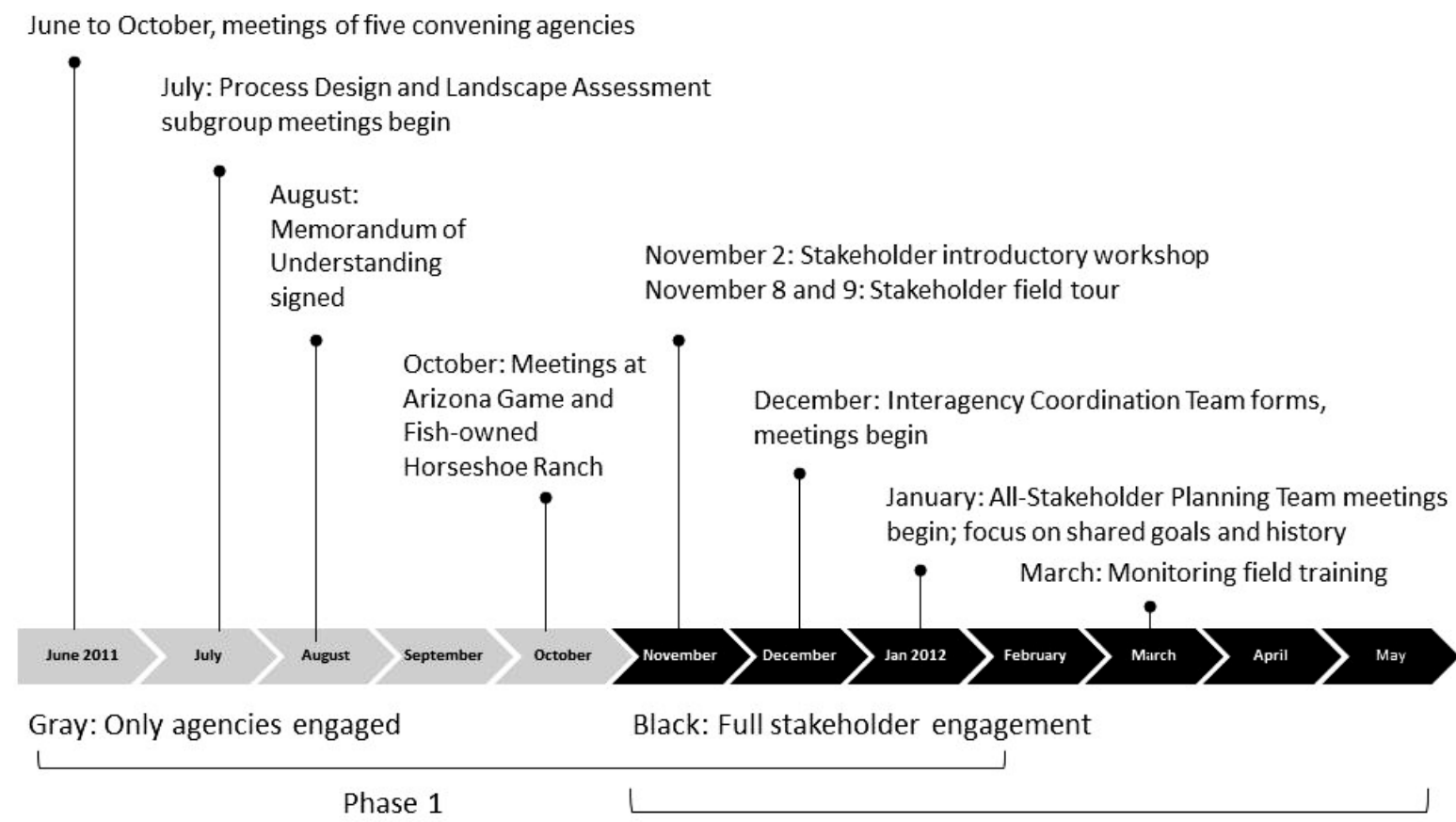

Phase 2

organizations, environmental advocates, and organizations who had attended at least one meeting. The third round of interviews was with stakeholders that had not attended, but had been identified as important by the agencies and nonagency stakeholders who had been interviewed previously. At the end of each interview, we asked if there was anyone missing from the process so far that would be helpful to speak to. This resulted in snowballing during interview phase three. In total, 31 stakeholders were interviewed (Fig. 2).

The lead researcher and the process facilitator conducted all interviews. Questions were designed to address the following topics: background, current activities, ecological conditions, collaboration, stakeholders, institutions, process design, concerns, values, goals, and motivations. ${ }^{[1]}$

The coding process was initiated with a data-reduction process to presort large sections of interview data into manageable segments (Bringer et al. 2006). The analysis process allowed for inductive themes to emerge naturally. Interview data were organized using MAXQDA qualitative data-coding software. In the first round of data reduction, responses from the interviews were gathered and analyzed within five start themes called "parent nodes" (Miles and Huberman 1994): goals and motivations, stakeholders, collaboration, process design, and adaptive management. In the second phase of data reduction, data within each broad topic were coded more specifically to develop a detailed set of descriptive codes, or "child nodes", using participants' words whenever possible. After multiple iterations of child-node refinement, a final codebook was developed to enable consistent use of codes by the researcher (Miles and Huberman 1994). Once the coding protocols were finalized, two researchers independently coded a random sample of text units to establish inter-rater reliability using Cohen's (1960) Kappa coefficient. One of the examples of disagreement by the coders was when both examined the following statement, "But deciding how you're going to manage grazing before you look at a range of alternatives about whether or not grazing's even appropriate is, to me, kinda front-loading the decision making." There was agreement that this was "social barrier," but disagreement at the child node level where one researcher coded it as "distrust of government" and the other as "interpersonal friction." After discussion regarding disagreements with the coding protocol, the independent coders recoded a sample of statements. Final Kappa coefficients were: Overall .942 (Very Good), Social Strengths 1.00 (Perfect), Social Barriers 1.00 (Perfect), Structural Barriers .778 (Very Good), and Structural Strengths 1.00 (Perfect). 


\section{RESULTS AND DISCUSSION}

After the four iterations of coding, we found that social cohesion encouraged commitment, and were identified factors that positively and negatively influenced trust between individuals in the earliest stages of a new comanagement arrangement. Social variables refer to the attributes of subjects or interactions between people and organizations (Plummer 2009) including personal motivations, evaluations of current and future social dynamics, and events that impact personal relationships. But the objects of the process (Ozawa 2012), such as meetings, key roles, and rules, also heavily influenced social dynamics. Meeting design could positively or negatively impact the interpersonal relationships, trust, and motivations of participating individuals.

\section{Building trust and commitment}

When asked about process design, goals, and collaboration experience, all interviewees commented on past experience or expectations of working in teams. Participant responses illuminated two important social foundations: (1) early unity, and (2) shared commitment to participation.

Our results indicated that participants believed that creating a connection to place and developing a set of galvanizing factors were critical to building unity early in the process. Though the participant's resource interests were diverse, these natural and cultural resources created a bond between the individual and the land. One facilitation team member summarized it by saying the group was unified around the "amazing resources. Beautiful grassland. Nice riparian. You want to be there." She described the resources, especially Perry Mesa for its nationally significant cultural components, as a foundation of the whole planning effort. This connection inspired stakeholders to stay committed because "these things are worth working on." This case presented a small-scale resource context, which reduced the complexities that make comanagement challenging (Plummer and Armitage 2007). An innovative project for management of cultural, prehistoric resources on the Perry Mesa further mobilized the group. During the November field tour, one archaeologist suggested the coordinated resource management plan should include restoration projects of prehistoric sites such as check dams and terraces. These restoration projects would increase public recreation access and encourage public participation while integrating findings from scientific studies of prehistoric soil and water systems. These restoration ideas ignited engagement from the cultural resource community. Many in the community expressed fatigue with the traditional protection and preservation approach to management of cultural resources termed "keep under lock and key". The restoration idea energized participants as "an opportunity to bring ecologists and cultural resource people together in a way that seldom happens". By expanding and further developing the set of issues that the project focused on, a wave of excitement and feeling of unity deepened. Wondolleck and Yaffee (2000) point out that trust of government can be increased by deliberately "building bridges" between decision makers and people on the ground. In this case, sharing information and unifying around projects that excited both parties signaled an alignment between traditionally distrustful government and nongovernment groups.

Participants believed that it was critical to have widespread support of collaborative management and trust in the leadership in order to commit to the process. Stakeholders expressed positive support for participating in an adaptive, collaborative approach to land management. This remains true across the board despite varying comfort levels with inclusive stakeholder engagement, resource availability, staff capacity, and predefined grazing use. Individuals responded that working together results in improved learning and richer knowledge, which are attributes of organizations and individuals that influence the process of adaptive comanagement (Plummer 2009). A handful of stakeholders expressed frustrations with the premonitoring decision to graze but still want to participate to ensure the impacts of grazing were well documented and incorporated into future decisions. Despite having individual concerns, people with diverse interests agreed to work together to achieve the shared goal of producing on-the-ground improvements and to test for success through high-quality monitoring (Wondolleck and Yaffee 2000, Plummer and Armitage 2007). One interviewee that was not interested in participating said that no outcome would be worth her time, because the decision to graze was harmful and irreversible, reflecting what Klijn and Skelcher (2007) describe as an issue of transition, or in this case a lack of transition. Power has not completely shifted out of the hands of government and into the broader governance network, which limited the authority of the Agua Fria Adaptive CoManagement Planning Committee, and thus the interests of one anti-grazing environmentalist.

The leaders of each convening agency were viewed positively by all stakeholders, even if their organizations as a whole were viewed negatively. Many respondents acknowledged that agencies appeared engaged and eager to learn despite their newness to inclusive collaboration. Also, supervisors of participants were supportive. Senior leaders in the Bureau of Land Management, Arizona Game and Fish Department, and Tonto National Forest supported this collaborative effort; leadership is an important variable influencing adaptive comanagement processes (Plummer 2009) and emerging trust of leadership is one of the strengths of this case. Similarly, nonagency stakeholders were either organizational leaders or had strong buy-in from their organizations to participate. The strength of this support, however, was tenuous because collaboration is not yet institutionalized across multiple levels of government, and it is unclear how much decision-making authority would reside with the agencies, the planning team, or the broader governance network as a whole. Participants 
within the agencies described how adaptive comanagement and the coordinated resource management plan were interpreted and reinterpreted as the process began to unfold. As of March 2012, there is strong support for Agua Fria adaptive comanagement, but there may be internal struggles within the agencies if new goals or policies conflict with the existing missions of the Bureau of Land Management, Tonto National Forest, or Arizona Game and Fish Department, or if support from institutions wanes.

\section{Importance of facilitation}

The composition of the facilitation team and the team-building activities were critical to the development of social trust and cohesion of the project members. The facilitation team came from diverse perspectives: one from Bureau of Land Management Tucson, one from The Nature Conservancy, and the lead facilitator was the owner of an environmental consulting firm. The facilitation team was unique because its members had experience working on adaptive comanagement at the Las Cienegas Conservation Area, which allowed them to incorporate lessons learned, which sped up the planning stages and enhanced agency leadership support. The facilitation team served a bridging function in the forms of coordinating interpersonal interactions and centralizing information, which are roles that others have found critical in adaptive comanagement (see for example, Olsson et al. 2007).

Multiple interviewees identified field meetings and the shared history exercise as trigger points that unified them and increased commitment going forward. Enthusiasm was strong at the end of the field tour and many attendees expressed a desire to continue meeting outdoors where participants could interact with the resources in a local context (Plummer and Armitage 2007). The connection to the land is one thing most actors have in common; meeting outdoors on the land further unified and invigorated the team. A facilitation team member described the field training:

\section{I will say that that tension largely dissipated over the two days spent in the field. Not all of it, but a lot of it. Where folks came in with the attitude of 'I don't see how this monitoring approach is going to include [my resource priority]. You're forgetting [my resource priority].' Then pretty much a direct quote from one of the folks at the end of those two days was: "Boy, it seems like these are really going to be great for [my resource priority]. If these methods work out as well as they seem to, maybe we can use them elsewhere.}

Even though this particular method had been discussed in two previous meetings, it was not until the group got out into the field to test it that participants began to unify around its utility.

Combining knowledge from experts and nonexperts also served to build trust and increase learning within the team
(Plummer and Armitage 2007). During the shared history exercise, participants spent 30 minutes creating a timeline on butcher paper. Then participants discussed this history collectively. According to one interviewee, "That timeline was fantastic. I loved that. I talked to so many people who were really upbeat. And it may have just been a feel-good thing, but it broadened the shared history between us." Another said, "I'm very optimistic. I like the shared history timeline. That was very revealing for me to understand everybody's position and their perspective." The shared history and field meetings unified participants, building commitment for adaptive comanagement both within and outside agencies.

\section{Managing threats}

There needs to be an arena where diverse actors can meet to share knowledge, learn, and identify shared interests (Olsson et al. 2007). Bridging organizations or teams can facilitate interactions between actors to resolve conflicts and build trust (Stockholm Resilience Centre 2012). In this case, the facilitation team served a bridging function by creating a space for actors to resolve conflict, as well as discuss and learn from data and ecosystem feedback; this bridging function has been found in other successful comanagement projects (see for example Hahn et al. 2006). Without the facilitation team to link diverse actors and create safe space for social learning, early conflict events may not have been addressed openly and constructively.

Stakeholders shared concerns and potential barriers to collaboration, only some of which could be mediated through professional facilitation. In this case, social trust faced several threats such as lack of trust in government commitment, collaborative fatigue, and dealing with history of interpersonal conflict between participants. In addition to the concern about conflicts, several structural challenges also presented themselves in the early collaborative stages: time constraints, funding constraints, and missing mechanisms for documenting shared decision making. As of yet, the team has not tackled these pressing issues, but the commitment to building interpersonal relationships and effective facilitation processes bodes well for its ability to solve emerging problems. Overall, the interviews supported the existing literature that stresses that social factors are critical for adaptive comanagement. Trust building prepares people and institutions to adapt to change (Olsson et al. 2007, Stockholm Resilience Centre 2012). Negotiation theorists suggest that social trust occurs when actors come to depend on one another to achieve goals because they understand they will not succeed without agreement between multiple groups (Ozawa 2012). Nearly every person interviewed agreed that working across disciplines and organizations is important, but they hesitated to trust the team's commitment because of poor past experiences with each other and other collaborations. Early confidence was enhanced through activities such as shared history, field meetings, and facilitation. By identifying 
galvanizing factors, actors could start working toward mutually beneficial goals, which may keep them united when presented with challenges in the future. Unlike many wellknown adaptive comanagement cases initiated from the bottom up by stakeholders (Hahn 2011), e.g., Kristianstad (Olsson et al. 2007), Agua Fria stakeholders were brought together by the agencies to solve a comanagement challenge by scaling up an existing process developed at Las Cienegas.

Thus the facilitation team faced a challenge of developing the trust and commitment to the project and process in addition to maintaining momentum. Some participants were frustrated by the coordinated resource management plan at the beginning, but by effectively taking particular decisions off the table, e.g., whether or not to allow grazing, the team was able to focus on somewhat less contentious issues such as the importance of the cultural resources and building a shared history and sense of place. The planning team expressed a strong desire to maintain a sense of progress at each consecutive meeting. This presented a challenge because early meetings require planning and initial process-design conversations, which can be draining for participants who most enjoy being close to the resources, but these early meetings reflected a commitment to building a process that shared decision-making authority that would be supported internally within the agencies and externally with the wider governance network. The facilitation team recognized this challenge and intends to balance activities that contribute to a sense of progress and connection to place. The project leadership is building upon an emerging set of governance tactics, which incorporate systems thinking and inclusive participation (Pahl-wostl et al. 2007, Plummer and Armitage 2007). There was a need in this case to mobilize around shared goals, such as the cultural and ecological resources, as well as the sense of a treasured history of the land, which reflects lessons from other cases (e.g., Wondolleck and Yaffee 2000).

Caution should be exercised when building upon and scaling up existing projects, particularly as government agencies require or encourage adaptive comanagement processes (Kagan 1999, Lubell 2004). But, our case illustrates that lessons regarding process and facilitation from a longenduring project, Las Cienegas, were transferable, as long as the shared goals and structures developed for management were place specific. This is a newly emerged project, but early lessons indicate that processes that enhance social relationships have been translated to commitment and preliminary action, which contrasts with some of the more cautionary cases where intention into action did not occur (Kenney 2000, Susskind et al. 2010). The shared decision making occurs largely through influence instead of through the legal authority of Agua Fria, so it is critical that the agencies and planning team maintain trust, commitment, and cohesion through beliefs that shared decisions are put in to action. As
Klijn and Skelcher (2007) argue, governance networks are not necessarily equitable, but rather interdependent; in our case, the federal agencies gave up some of their agenda-setting and policy-making authority to the planning committee with stakeholders at the table, but the Bureau of Land Management, Tonto National Forest, and Arizona Game and Fish Department, in cooperation with the permittee, retain decision-making authority for on-the-ground implementation. The group has successfully navigated early conflict by the creation of institutional mechanisms to deal with interpersonal or interagency disagreements and applying significant facilitator time and effort to maintain unity and commitment, but only time will tell whether the group is able to deal with the trickier structural issues, such as lack of agency and stakeholder time, collaborative fatigue, and cost.

\section{CONCLUSION}

Effective adaptive comanagement requires adaptive social processes and the achievement of ecological objectives. Both are critical to success, but strong social dynamics are especially important in the nascent stages of adaptive comanagement. Through trust building the team can better navigate the inevitable barriers to success. Recognition of the need for a bridging organization, or professional facilitation, led to discussions about assuring funding to support the facilitation team. The bridging organization in turn will be able to hold those key individuals accountable for putting time and energy into planning meaningful engagement and into maintaining a sense of progress, connection, and purpose. Within a governance network, maintenance of these factors via facilitation is especially importance because decisionmaking authority is blurred and stakeholders may question whether and who is accountable to whom.

A strong connection to place is the early glue that holds the team together, but the long-term sealant will come from institutionalizing collaboration processes and achieving desired goals. Establishment of a planning team led to shared goals for the project, but the day-to-day accountability, i.e., how the operational decisions of agencies interface with the comanagement process, remains murky. This is an emerging accountability concern that needs to be managed to maintain the adaptive comanagement process in the future; like other governance networks, accountability issues emerge because shared decision-making shifts some authority from government agencies and the representative democratic process, thus allowing some groups more access and influence, while others may actually have less (Hahn 2011).

Careful coding of interviews with managers and participants in the Agua Fria adaptive comanagement case allowed us to understand what challenges and strengths participants perceived during the initial months of adaptive comanagement. In future work we plan to extend this study in two ways: (1) focus on additional emerging cases to better 
understand the generalizability of our findings, and (2) empirically evaluate how new and long-enduring adaptive comanagement processes affect "on-the-ground" management decisions and ecological outcomes. In terms of governance networks, does adaptive comanagement lead to better policy outputs through a more transparent and open public consultation process? Answers to these questions will provide evidence of "effectiveness" within adaptive comanagement processes, as well as more broadly for governance networks.

Scientists and practitioners are working to bring about a cultural shift towards landscape-scale collaborative adaptive management. To accomplish this in the long-term, they must build trust and maintain meaningful engagement in the short term. These themes increase the likelihood of this collaboration "sticking" past the first 10 months. In the first phase of adaptive comanagement, several points of conflict emerged that had the potential to derail positive progress. However, through the guidance and problem-solving abilities of the facilitation team - the bridging organization in this case - these tension events were viewed as adjustments rather than "derailers". For newly emerging adaptive comanagement processes, attention should be paid to building trust, establishing meaningful engagement, and maintaining accountability. In this emerging process, it is unclear whether decisions and goals established by the adaptive comanagement planning team will translate to agency decisions both within and outside the boundaries of the project area. But, as one of the Bureau of Land Management's "test cases", the early success of Agua Fria surely foreshadows continued scaling of interagency, stakeholder adaptive comanagement governance networks across the western United States.

Responses to this article can be read online at:

http://www.ecologyandsociety.org/issues/responses. php/5636

\section{Acknowledgments:}

We thank the Bureau of Land Management, Tonto National Forest, and Arizona Game and Fish staff for allowing us to observe this emerging adaptive comanagement project. We also thank the stakeholders and agency staff who shared their invaluable knowledge and time with us. Tahnee Robertson, the lead facilitator, also provided critical feedback and created an interview environment productive for research and practice. Finally, we would like to thank Helen Rowe for connecting us to the newly emerging Agua Fria project and Curtis Koyama for transcription assistance.

\section{LITERATURE CITED}

Agranoff, R. I., and M. McGuire. 2001. Big questions in public network management research. Journal of Public Administration Research and Theory 11(3):295-326.

Allen, L. 2002. Wildlands of the west: the story of the Bureau of Land Management. National Geographic Society, Washington, D.C., USA.

Ansell, C., and A. Gash. 2007. Collaborative governance in theory and practice. Journal of Public Administration Research and Theory 18:543-571. http://dx.doi.org/10.1093/ jopart/mum032

Armitage, D. 2005. Adaptive capacity and community-based natural resource management. Environmental Management 35:703-15. http://dx.doi.org/10.1007/s00267-004-0076-z

Armitage, D., F. Berkes, and N. C. Doubleday. 2007. Introduction: moving beyond co-management. Pages 1-15 in D. Armitage, F. Berkes, and N. C. Doubleday, editors. Adaptive co-management: collaboration, learning, and multilevel governance. UBC Press, Vancouver, British Columbia, Canada.

Armitage, D. R., R. Plummer, F. Berkes, R. I. Arthur, A. T. Charles, I. J. Davidson-Hunt, A. P. Diduck, N. C. Doubleday, D. S. Johnson, M. Marschke, P. McConney, E. W. Pinkerton, and E. K. Wollenberg. 2009. Adaptive co-management for social-ecological complexity. Frontiers in ecology and the environment 7:95-102. http://dx.doi.org/10.1890/070089

Bardach, E. 1998. Getting agencies to work together: the practice and theory of managerial craftsmanship. Brookings Institution Press, Washington, D.C., USA.

Berkes, F. 2002. Cross-scale institutional linkages: perspectives from the bottom up. Pages 293-321 in E. Ostrom, T. Dietz, N. Dolsak, P. Stern, S. Stonich, and E.U. Weber, editors. The drama of the commons. National Academy Press, Washington, D.C., USA.

Bringer, J., L. H. Johnston, and C. Brackenridge. 2006. Using computer-assisted qualitative data analysis software to develop a grounded theory project. Field Methods 18:245-266. http://dx.doi.org/10.1177/1525822X06287602

Caves, J., G. S. Bodner, K. Simms, L. Fisher, and T. Robertson. 2013. Integrating collaboration, adaptive management, and scenario-planning: experiences at Las Cienegas National Conservation Area. Ecology and Society 18(3):43. http://dx. doi.org/10.5751/ES-05749-180343

Carlsson, L., and F. Berkes. 2005. Co-management: concepts and methodological implications. Journal of Environmental Management 75:65-76. http://dx.doi.org/10.1016/j.

jenvman.2004.11.008 
Cohen, J. 1960. A coefficient of agreement for nominal scales. Educational and Psychological Measurement 20(1):37-46. http://dx.doi.org/10.1177/001316446002000104

Colding, J., C. Folke, and F. Berkes. 2003. Navigating socialecological systems: building resilience for complexity and change. Cambridge University Press, New York, New York, USA.

Conley, A., and M. A. Moote. 2003. Evaluating collaborative natural resource management. Society and Natural Resources 16(5):371-386.

Creswell, J. W. 2009. Research design: qualitative, quantitative, and mixed methods approaches. Third edition. Sage Publications, Thousand Oaks, California, USA.

Daniels, S. E., and A. S. Cheng. 2004. Collaborative resource management: discourse-based approaches and evolution of TechnoReg?. Pages 127-136 in M. J. Manfredo, J. V. Vaske, B. L. Bruyere, D. R. Field, and P. J. Brown, editors. Society and natural resources: a summary of knowledge. Modern Litho, Jefferson, Montana, USA.

Dietz, T., E. Ostrom, and P. C. Stern. 2003. The struggle to govern the commons. Science 302:1907-12. http://dx.doi. org/10.1126/science.1091015

Fernández-Giménez, M. E., S. Le Febre, A. Conley, and A. Tendick. 2004. Collaborative stewardship of Arizona's rangelands. Rangelands 26(6):24-30.

Filbin, G. et al. 1997. Community-based environmental protection: a resource book for protecting ecosystems and communities. EPA 230-B-96-003. Office of Policy, Planning, and Evaluation, U.S. Environmental Protection Agency, Washington, D.C., USA.

Folke, C., T. Hahn, P. Olsson, and J. Norberg. 2005. Adaptive governance of social-ecological systems. Annual Review of Environment and Resources 30:441-473. http://dx.doi. org/10.1146/annurev.energy.30.050504.144511

Folke, C., Å. Jansson, J. Rockström, P. Olsson, S. R. Carpenter, S. C. III, A.-S. Crépin, G. Daily, K. Danell, J. Ebbesson, T. Elmqvist, V. Galaz, F. Moberg, M. Nilsson, H. Österblom, E. Ostrom, A. Persson, G. Peterson, S. Polasky, W. Steffen, B. Walker, and F. Westley. 2011. Reconnecting to the biosphere. AMBIO: A Journal of the Human Environment 40:7:719-738. http://dx.doi.org/10.1007/ s13280-011-0184-y

Glaser, B. 1992. Basics of grounded theory analysis: emergence vs. forcing. Sociology Press, Mill Valley, California, USA.

Gray, M., and J. Kalpers. 2005. Ranger based monitoring in the Virunga-Bwindi region of East-Central Africa: a simple data collection tool for park management. Biodiversity and
Conservation 14:2723-2741. http://dx.doi.org/10.1007/ s10531-005-8406-X

Gunderson, L., and C. S. Holling. 2002. Panarchy: understanding transformations in human and natural systems. Island Press, Washington, D.C., USA.

Hahn, T. 2011. Self-organized governance networks for ecosystem management: who is accountable? Ecology and Society 16(2):18. [online] URL: http://www.ecologyandsociety. org/vol16/iss2/art18/.

Hahn, T., P. Olsson, C. Folke, and K. Johansson. 2006. Trustbuilding, knowledge generation and organizational innovations: the role of a bridging organization for adaptive comanagement of a wetland landscape around Kristianstad, Sweden. Human Ecology 34:573-592. http://dx.doi. org/10.1007/s10745-006-9035-Z

Hall, T. E., and D. D. White. 2008. Representing recovery: science and local control in the framing of U.S. Pacific Northwest salmon policy. Human Ecology 15:32-45.

Hemingway, J. L. 1990 . Opening windows on an interpretive leisure studies. Journal of Leisure Research 22:303-308.

Holling, C. S. 1978. Adaptive environmental management. John Wiley and Sons, New York, New York, USA. http://dx. doi.org/10.1080/00139157.1986.9928829

Huitema, D., E. Mostert, W. Egas, S. Moellenkamp, C. PahlWostl, and R. Yalcin. 2009. Adaptive water governance: assessing the institutional prescriptions of adaptive (co-) management from a governance perspective and defining a research agenda. Ecology and Society 14(1):26. [online] URL: http://www.ecologyandsociety.org/vol14/iss1/art26/.

Kagan, R. 1999. Trying to have it both ways: local discretion, central control, and adversarial legalism in American environmental regulation. Ecology Law Quarterly 25:718-732.

Kasperson, R., D. Golding, and S. Tuler. 1992. Social distrust is a factor in siting hazardous facilities and communicating risks. Journal of Social Issues 48:161-187. http://dx.doi. org/10.1111/j.1540-4560.1992.tb01950.x

Kenney, D. 2000. Arguing about consensus. University of Colorado School of Law, Boulder, Colorado, USA.

Klijn, E-H, and C. Skelcher. 2007. Democracy and governance networks: compatible or not? Public Administration 85 (3):587-608..

Kruse, M. 2007. The agricultural landscape of Perry Mesa: modeling residential site location in relation to arable land. Kiva 73:85-102.

Lee, K. 1999. Appraising adaptive management. Ecology and Society 3(2):3. [online] URL: http://www.ecologyandsociety. org/vol3/iss $2 /$ art $3 /$. 
Lubell, M. 2004. Collaborative environmental institutions: all talk and no action? Journal of Policy Analysis and Management 23(3):549-573.

Miles, M., and M. Huberman. 1994. Qualitative data analysis. Second edition. Sage Publications, Thousand Oaks, California, USA. http://dx.doi.org/10.2307/2392365

Olsson, P., C. Folke, and F. Berkes. 2004a. Adaptive comanagement for building resilience in social-ecological systems. Environmental Management 34:75-90.

Olsson, P., C. Folke, V. Galaz, T. Hahn, and L. Schultz. 2007. Enhancing the fit through adaptive co-management: creating and maintaining bridging functions for matching scales in the Kristianstads Vattenrike Biosphere Reserve, Sweden. Ecology and Society 12(1):28. [online] URL: http://www. ecologyandsociety.org/vol12/iss 1/art28/.

Olsson, P., C. Folke, and T. Hahn. 2004b. Social-ecological transformation for ecosystem management: the development of adaptive co-management of a wetland landscape in southern Sweden. Ecology and Society 9(4):2. [online] URL: http:// www.ecologyandsociety.org/vol9/iss4/art2/.

Ostrom, E. 2005. Understanding institutional diversity. Princeton University Press, Princeton, New Jersey, USA.

Ostrom, V. 1993. Epistemic choice and public choice. Public Choice 77:163-176. http://dx.doi.org/10.1007/BF01049230

Ozawa, C. P. 2012. Planning resilient communities: insights from experience with risky technologies. Pages 19-39 in B. E. Goldstein, editor. Collaborative resilience: moving through crisis to opportunity. MIT Press, Cambridge, Massachusetts, USA.

Pahl-wostl, C., M. Craps, A. Dewulf, E. Mostert, D. Tabara, and T. Taillieu. 2007. Social learning and water resources management. Ecology and Society 12(2):5. [online] URL: http://www.ecologyandsociety.org/vol12/iss2/art5/.

Patton, M. Q. 1990. Qualitative evaluation and research methods. Sage Publications, Thousand Oaks, California, USA.

Plummer, R. 2009. The adaptive co-management process: an initial synthesis of representative models and influential variables. Ecology and Society 14(2):24. [online] URL: $\underline{\text { htp:// }}$ www.ecologyandsociety.org/vol14/iss2/art24/.

Plummer, R., and D. Armitage. 2007. A resilience-based framework for evaluating adaptive co-management: Linking ecology, economics and society in a complex world. Ecological Economics 61:62-74. http://dx.doi.org/10.1016/j. ecolecon.2006.09.025

Plummer, R., and J. Fitzgibbon. 2004. Some observations on terminology in cooperative environmental management.
Journal of Environmental Management 70:63-72. http://dx. doi.org/10.1016/i.jenvman.2003.10.005

Polasky, S., S. R. Carpenter, C. Folke, and B. Keeler. 2011. Decision-making under great uncertainty: environmental management in an era of global change. Trends in Ecology and Evolution 26(8):398-404. http://dx.doi.org/10.1016/j. tree.2011.04.007

Pomeroy, R. 2007. Conditions for successful fisheries and coastal resources co-management: lessons learned in Asia, Africa, and the wider Caribbean. Pages 173-187 in D. Armitage, F. Berkes, and N. C. Doubleday, editors. Adaptive co-management: collaboration, learning, and multi-level governance. UBC Press, Vancouver, British Columbia, Canada.

Pomeroy, R., and F. Berkes. 1997. Two to tango: the role of government in fisheries co-management. Marine Policy 21:465-480. http://dx.doi.org/10.1016/S0308-597X(97)00017-1

Poulsen, M. K., and K. Luanglath. 2005. Projects come, projects go: lessons from participatory monitoring in southern Laos. Biodiversity and Conservation 14:2591-2610. http://dx. doi.org/10.1007/s10531-005-8390-1

Rockström, J., W. Steffen, K. Noone, Å. Persson, I. F. Stuart Chapin, E. F. Lambin, T. M. Lenton, M. Scheffer, C. Folke, H. J. Schellnhuber, B. Nykvist, C. A. de Wit, T. Hughes, S. van der Leeuw, H. Rodhe, S. Sörlin, P. K. Snyder, R. Costanza, U. Svedin, M. Falkenmark, L. Karlberg, R. W. Corell, V. J. Fabry, J. Hansen, B. Walker, D. Liverman, K. Richardson, P. Crutzen, and J. A. Foley. 2009. A safe operating space for humanity. Nature 461:472-475. http://dx.doi.org/10.1038/461472a

Ruitenbeek, J., and C. Cartier. 2001. The invisible wand: adaptive co-management as an emergent strategy in complex bio-economic systems. Occasional Paper 34. Center for International Forestry Research, Bogor, Indonesia.

Schwandt, T. A. 1994. Constructivist, interpretivist approaches to human inquiry. Pages 118-137 in N. K. Denzin and Y. S. Lincoln, editors. Handbook of qualitative research. Sage Publications, London, UK.

Shmueli, D. F., S. Kaufman, and C. Ozawa. 2008. Mining negotiation theory for planning insights. Journal of Planning Education and Research 27:359-364. http://dx.doi. org/10.1177/0739456X07311074

Steffen, E., P. J. Crutzen, and J. R. McNeill. 2007. The anthropocene: are humans now overwhelming the great forces of nature? AMBIO: A Journal of the Human Environment 36:614-621.

Stockholm Resilience Centre. 2012. Adaptive governance: governance of social-ecological systems in an increasingly uncertain world needs to be collaborative, flexible and 
learning-based. Research Insights: Insight \#3. Stockholm University, Stockholm, Sweden.

Stone, C. 2007. From National Register District to National Monument: the past ten years on Perry Mesa. Agua Fria National Monument, Phoenix District, Bureau of Land Management, US Department of the Interior, Phoenix, Arizona.

Stoker, G. 1998. Governance as theory: five propositions. International Social Science Journal 50(155):17-28. http://dx. doi.org/10.1111/1468-2451.00106

Strauss, A., and J. Corbin. 1998. Basics of qualitative research: techniques and procedures for developing grounded theory. Second edition. Sage Publications, London, UK.

Susskind, L., A. E. Camacho, and T. Schenk. 2010. Collaborative planning and adaptive management in Glen Canyon: a cautionary tale. Columbia Journal of Environmental Law 35(1).

Tàbara, J. D., and C. Pahl-wostl. 2007. Sustainability learning in natural resource use and management. Ecology and Society 12(2):3. [online] URL: http://www.ecologyandsociety.org/ vol12/iss2/art3/.

U.S. Department of Agriculture. 2007. Arizona NRCS Coordinated Resource Management Plan guidance. National Planning Procedures Handbook, Arizona Supplement, March 2007. Natural Resources Resources Conservation Service, U. S. Department of Agriculture, Washington, D.C, USA.

Uychiaoco, A. J., H. O. Arceo, S. J. Green, M. T. De La Cruz, P.A. Gaite, and P. M. Aliño. 2005. Monitoring and evaluation of reef protected areas by local fishers in the Philippines: tightening the adaptive management cycle. Biodiversity and Conservation 14. http://dx.doi.org/10.1007/s10531-005-8414$\underline{\mathrm{x}}$

Van Damme, J., and M. Brans. 2012. Managing public consultation: a conceptual framework and empirical findings from Belgian case studies. Public Administration 90 (4):1047-1066. http://dx.doi.org/10.1111/j.1467-9299.2011.02014. $\underline{\mathrm{X}}$

Walters, C. 1997. Challenges in adaptive management of riparian and coastal ecosystems. Conservation Ecology 1 (2):1.

White, D. D. 2007. An interpretive study of Yosemite National Park visitors' perspectives toward alternative transportation in Yosemite Valley. Environmental Management 39 (1):50-62. http://dx.doi.org/10.1007/s00267-006-0061-9

Wondolleck, J., and S. Yaffee. 2000. Making collaboration work. Island Press, Washington, D.C., USA.

${ }^{[1]}$ Tribe representatives were missing because of sensitive federal-tribal relationships. Federal agencies preferred to maintain a separate and parallel conversation with tribal representatives about the CRMP, so tribal representatives were not contacted for this study. 